\title{
Relação das dissertações defendidas no Programa de Pós-Graduação Stricto Sensu em Educação da Universidade São Francisco no período de julho a dezembro de 2013
}

FRANCO, Maria Cristina Muñoz. Jogos discursivos e governamentalidade: tecendo efeitos de sentido sobre sustentabilidade. 2013. Dissertação (Mestrado em Educação). Programa de Pós-Graduação Stricto Sensu em Educação. Universidade São Francisco, Itatiba/SP. Orientadora: Profa. Dra. Alexandrina Monteiro.

A emergência das questões ambientais pode ser considerada uma das principais marcas da Contemporaneidade, e é nesse contexto que os discursos sobre sustentabilidade emanam como mantras sobre as formas de entender os problemas e encaminhar possíveis soluções. Considerando os discursos como práticas que geram significados e que constituem os sujeitos através das subjetivações criadas pelos próprios discursos, proponho neste trabalho uma análise discursiva sobre sustentabilidade com base no encarte do projeto Planeta Sustentável, publicado na Revista Nova Escola abordando a conferência Rio + 20, em que me interessa problematizar os efeitos de sentido desse discurso e de que forma eles atravessam as práticas de educação ambiental. Este trabalho pauta-se na perspectiva discursiva, pós-estruturalista e foucaultiana, fazendo uso do conceito de governamentalidade como ferramenta analítica para examinar a complexidade das relações envolvidas em práticas de governamento através das quais a verdade é produzida.

SOUZA, Elizandra Rodrigues de. Subjetividade adolescente: identificação, alteridade e discurso. 2013. Dissertação (Mestrado em Educação). Programa de Pós-Graduação Stricto Sensu em Educação. Universidade São Francisco, Itatiba/SP. Orientadora: Profa. Dra. Márcia Aparecida Amador Mascia.

Esta pesquisa, se insere na linha de Linguagem, Discurso e Práticas Educativas, e se propôs estudar a constituição do sujeito-adolescente, tendo como base para seu desenvolvimento teórico os pressupostos da análise do discurso, de linha francesa, as construções foucaultianas no que tange à terceira fase deste autor, da "escrita de si" ou do "cuidado de si" e, também, os postulados psicanalíticos no que refere ao sujeito. Desta forma, a questão central que se levanta é como se constitui a adolescência, através das formações discursivas veiculadas pelo próprio adolescente. Assim, colocamos que a adolescência não pode mais ser vista como 'fase de transição', pois o dizer do adolescente nos remete a instituir a adolescência como uma posição subjetiva. A pesquisa se justifica face às grandes confusões sobre o que é a adolescência e sobre sua importância, tanto nos aspectos sociais, físicos e biológicos, como nos aspectos psicológicos e culturais. Nossa diferenciação frente a outras pesquisas se situa no fato de recolher do próprio adolescente os dizeres sobre esse lugar. Ninguém melhor que o adolescente para dizer sobre si mesmo e sobre esta posição-sujeito que gera controvérsias externas estudiosos, especialistas, pesquisadores, professores e pais - e internas - angústias, paixões, conflitos etc. Esta pesquisa quis, principalmente, dar voz ao adolescente, que em meio a tantos contextos ainda não consegue elaborar seus limites de existência, como também, colaborou para melhor entender os sujeitos contemporâneos, em especial, o adolescente, fugindo do estereótipo da "aborrescência". Recolhemos os dizeres dos adolescentes por três vias: telefone, internet e entrevistas. Através dos dizeres dos participantes, pudemos discutir e analisar a posição do adolescente na sociedade atual. Os dizeres exprimem opiniões sobre seus contextos de vida e daquilo que mais chama sua atenção, seja por dúvidas, por indignação, por sofrimento ou pela realidade. As relações com o outro foi a grande questão postulada pelos adolescentes. Seus dizeres inferem a importância do outro na sua constituição subjetiva e indicam que a alteridade é fundamental para a existência do sujeito. Outro fator relevante percebido nesta pesquisa é o apagamento da escola no dizer do adolescente, principalmente no que se refere à educação formal, ao conhecimento e a escola como possibilidade de crescimento pessoal e profissional. Dessa forma, percebemos que é possível entender que a adolescência se constitui como posição subjetiva, pois seu dizer expressa questões da sua constituição enquanto sujeito. 